\title{
Clinical trial update on bispecific antibodies, antibody-drug conjugates, and antibody-containing regimens for acute lymphoblastic leukemia
}

\author{
Delong Liu ${ }^{1^{*}}$ (D), Juanjuan Zhao ${ }^{2}$, Yongping Song ${ }^{2}$, Xiaofeng Luo ${ }^{3}$ and Ting Yang ${ }^{3}$
}

\begin{abstract}
The relapse rate remains high after chemotherapy for adult patients with acute lymphoblastic leukemia (ALL). With better molecular diagnosis and classification as well as better assessment for minimal residual disease, major progress in the treatment for refractory and/or relapsed ALL is being made. In addition to the tyrosine kinase inhibitors (TKIs) for Philadelphia chromosome-positive ALL, immunotherapeutic agents, blinatumomab, inotuzumab ozogamicin (INO), and chimeric antigen receptor (CAR) T cells, are changing the treatment paradigm for ALL. Blinatumomab and INO are being incorporated into induction chemotherapy regimens and combined with TKIs for ALL therapy. A novel low-intensity regimen, miniHCVD-INO-blinatumomab, appears to be less toxic and more effective than conventional intensive chemotherapy regimens. This review summarized new therapeutic researches of ALL and updated latest progress in clinical trials on bispecific antibodies, antibody-drug conjugates, and new regimens incorporating these novel antibodies.
\end{abstract}

Keywords: Acute lymphoblastic leukemia, Bispecific antibody, Antibody-drug conjugate, Chimeric antigen receptor, Hyper-CVAD

\section{Background}

Although high response rate is achieved from the chemotherapy for acute lymphoblastic leukemia (ALL), there is still high relapse rate for adult ALL patients [1-6]. The prognosis of adults with relapsed/refractory $(\mathrm{R} / \mathrm{R})$ ALL is still very poor $[7,8]$. With better molecular diagnosis and classification as well as better assessment for minimal residual disease, major progress in the treatment for R/R ALL is being made [9-11]. Five tyrosine kinase inhibitors (TKIs) are available for chronic myeloid leukemia, and TKIs have made clear contribution to the improvement of outcome in patients with Philadelphia chromosome-positive $(\mathrm{Ph}+) \mathrm{ALL}$ [12-18]. In addition to the TKIs, immunotherapeutic agents, blinatumomab, inotuzumab ozogamicin (INO), and chimeric antigen receptor (CAR) $\mathrm{T}$ cells are changing the treatment paradigm for ALL [19-29]. Hyper-CVAD is a

\footnotetext{
* Correspondence: DELONG_LIU@NYMC.EDU

'Department of Oncology, The First Affiliated Hospital of Zhengzhou

University, Zhengzhou 450052, China

Full list of author information is available at the end of the article
}

commonly used chemotherapy regimen for ALL and has served as a backbone for the development of new regimens [30-36]. When CD20 expression is present, rituximab is added to chemotherapy regimens [37-41]. Blinatumomab and INO are being investigated in clinical trials for their incorporation into chemotherapy regimens and combined with TKIs for ALL therapy. The new low-intensity combination regimen, miniHCVD-INO-blinatumomab, appears to be less toxic and more effective. This review summarized new therapeutic researches of ALL and updated latest progress in clinical trials on bispecific antibodies, antibody-drug conjugates, and new regimens incorporating these novel antibodies.

\section{Bispecific T cell-engaging (BiTE) antibodies Blinatumomab}

The human CD19 antigen is a transmembrane protein expressed from pre-B cells until the terminal differentiation to plasma cells [42]. CD19 is a critical component of B cell receptor multicomplex [43]. Therefore, CD19 
remains as the most reliable surface biomarker for $\mathrm{B}$ cells $[44,45]$. CD19 is the most commonly targeted antigen to date in immunotherapy for hematological malignancies [46-48].

Blinatumomab (blina) is a novel first-in-human BiTE antibody against CD19/CD3 that is designed to bind specifically to CD19+ B cells and CD3+ T cells, resulting in $\mathrm{T}$ cell activation and a cytotoxic $\mathrm{T}$ cell response against CD19-expressing cells [49]. Blina is produced through recombinant DNA technology [50-54]. Blina is an antibody fragment with a molecular weight of 55 $\mathrm{kDa}$. Therefore, its biological half-life is short and continuous IV infusion is required $[55,56]$. Similar to the infusion of CAR $\mathrm{T}$ cells, cytokine release syndrome (CRS) and neurotoxicity are the major adverse events from blina therapy $[25,57-60]$. In order to minimize CRS and neurotoxicities, it is recommended that the drug be used in a dose-escalating manner, with $9 \mu \mathrm{g} / \mathrm{day}$ for the first week, followed by $28 \mu \mathrm{g} /$ day for the remaining 3 weeks $[25,51,59]$. Two weeks of treatment-free interval are recommended prior to the subsequent cycle. The FDA approved indications, dose, and schedules of blinatumomab administration are summarized in Table 1.

A phase II multicenter clinical trial evaluating the safety and efficacy of blinatumomab in adult $\mathrm{R} / \mathrm{R} \mathrm{Ph}-$ B-ALL reported 43\% CR rate [59]. Among these CR patients, $24-46 \%$ were then able to receive allogeneic hematopoietic stem cell transplantation (allo-HSCT) [25, $59,61]$. Blinatumomab is thus considered as an effective bridge therapy to allo-HSCT. The US FDA approved blinatumomab for the treatment of adult $\mathrm{R} / \mathrm{R} \mathrm{Ph}-\mathrm{B}$-ALL based on the phase II study [59]. Subsequently, a large randomized phase III trial comparing blinatumomab versus salvage chemotherapy for R/R B-ALL was reported [25]. This study enrolled 405 patients and randomized patients in a 2:1 ratio to receive blinatumomab (271 patients) or chemotherapy (134 patients). Compared to the chemotherapy group, the blinatumomab group had a significantly longer overall survival (OS) (7.7 months vs 4.0 months, HR $0.71, p=0.01$ ) and a higher complete remission (CR) rate $(44 \%$ vs $25 \%, p<$ 0.001 ), further supporting blinatumomab as an efficacious and well-tolerated single-agent treatment option for R/R ALL.

Blina was also studied in B-ALL patients who had MRD+ after 3 months' frontline therapy or those who relapsed with MRD disease [61]. These patients were treated with blina following standard protocols up to 4 additional cycles. Patients who did not receive allo-HSCT were given maintenance blina therapy every 3 months for 4 cycles (a total of 9 cycles). TKI was added for $\mathrm{Ph}+\mathrm{ALL}$ patients at the discretion of treating physicians. A total of 17 patients were enrolled, with $3 \mathrm{Ph}+$ patients. Thirteen out of 17 patients (76\%) achieved MRD negativity, with 12 of the 13 patients being MRD

Table 1 Blinatumomab for B cell precursor acute lymphoblastic leukemia

\begin{tabular}{|c|c|c|}
\hline & Weight $\geq 45$ kg (fixed dose) & Weight < 45 kg (BSA-based dose) \\
\hline \multicolumn{3}{|c|}{ CR1 or CR2 with *MRD-positive patients } \\
\hline \multicolumn{3}{|l|}{ Cycles $1-4$} \\
\hline Days $1-28$ & $28 \mu \mathrm{g} /$ day & $15 \mu \mathrm{g} / \mathrm{m}^{2} /$ day (not to exceed $28 \mu \mathrm{g} /$ day) \\
\hline Days 29-42 & 14-day treatment-free interval & 14-day treatment-free interval \\
\hline \multicolumn{3}{|c|}{ Relapsed or refractory patients } \\
\hline \multicolumn{3}{|c|}{ Induction cycle 1} \\
\hline Days 1-7 & $9 \mu \mathrm{g} / \mathrm{day}$ & $5 \mu \mathrm{g} / \mathrm{m}^{2} /$ day (not to exceed $9 \mu \mathrm{g} /$ day) \\
\hline Days 8-28 & $28 \mu \mathrm{g} / \mathrm{day}$ & $15 \mu \mathrm{g} / \mathrm{m}^{2} /$ day (not to exceed $28 \mu \mathrm{g} /$ day) \\
\hline Days 29-42 & 14-day treatment-free interval & 14-day treatment-free interval \\
\hline \multicolumn{3}{|c|}{ Induction cycle 2} \\
\hline Days $1-28$ & $28 \mu \mathrm{g} / \mathrm{day}$ & $15 \mu \mathrm{g} / \mathrm{m}^{2} /$ day (not to exceed $28 \mathrm{\mu g} /$ day) \\
\hline Days 29-42 & 14-day treatment-free interval & 14-day treatment-free interval \\
\hline \multicolumn{3}{|c|}{ Consolidation cycles $3-5$} \\
\hline Days $1-28$ & $28 \mu \mathrm{g} /$ day & $15 \mu \mathrm{g} / \mathrm{m}^{2} /$ day (not to exceed $28 \mu \mathrm{g} /$ day) \\
\hline Days 29-42 & 14-day treatment-free interval & 14-day treatment-free interval \\
\hline \multicolumn{3}{|c|}{ Continued therapy cycles 6-9 } \\
\hline Days $1-28$ & $28 \mu \mathrm{g} / \mathrm{day}$ & $15 \mu \mathrm{g} / \mathrm{m}^{2} /$ day (not to exceed $28 \mu \mathrm{g} /$ day) \\
\hline Days 29-84 & 56-day treatment-free interval & 56-day treatment-free interval \\
\hline
\end{tabular}

$C R$ complete remission, $M R D$ minimal residual disease

*MRD is positive when blasts are $\geq 0.1 \%$ by flow cytometry in the bone marrow 
negative after the first cycle. Six of the $13(46 \%)$ patients received allo-HSCT due to donor availability. In a separate multicenter open-label single-arm study from Europe, blina treatment was given to adult B cell ALL patients with +MRD in CR1 or CR 2/3 which was defined by flow cytometry or PCR [62]. Among the 113 evaluable patients treated with blina, 88 patients $(78 \%)$ achieved MRD negativity. The median OS was 36.5 months. When the patients with complete MRD negativity (MRD responders) were compared with those in persistent +MRD (non-responders), MRD responders had longer relapse-free survival (RFS) (23.6 vs 5.7 months; $p$ $=.002)$ and OS (38.9 vs 12.5 months; $p=.002)$ than those in MRD non-responders. Therefore, it appears that blina is a good option to eliminate MRD after initial induction chemotherapy [63].

Blinatumomab has been approved for $\mathrm{Ph}-\mathrm{B}$ cell $\mathrm{R} / \mathrm{R}$ ALL. To evaluate the activity of blina in Ph+ R/R ALL patients, a phase II trial was started. The primary end point of the study was CR/CRh. In the first report of 45 such patients, CR/CRh was shown to be $36 \%$ (95\% CI, $22 \%$ to $51 \%$ ) during the first 2 cycles [64]. The responders included four of ten patients with the T315I mutation. Furthermore, the quality of the responses was striking, with MRD negativity in $88 \%$ of CR/CRh responders. Seven of the 16 responders $(44 \%)$ proceeded to allo-HSCT. The secondary endpoints of the study included median RFS and OS, which were 6.7 and 7.1 months, respectively. The major adverse events were similar to those reported in $\mathrm{Ph}$ - R/R ALL patients. The CRS and neurotoxicities were mild without grade 4 or 5 neurologic events.

Nevertheless, the $43 \%$ CR rate from blina in R/R ALL means that a significant proportion of patients was still considered treatment-resistant. The mechanisms of resistance to blinatumomab therapy are still poorly understood. One case report described that blinatumomab treatment failure was associated with an increase in number of ALL cells positive for programmed death-ligand 1 (PD-L1), which may be one of the underlying immune escape mechanisms [65]. This indicates that further investigation on the therapeutic potential of inhibitors of immune checkpoint molecules needs to be considered to overcome blinatumomab resistance. Another mechanism may be due to CD19 antigen loss as this was reported in relapsed patients after blina therapy $[66,67]$, though this appears to be less common than those seen after CAR T therapy $[28,68,69]$. To overcome this problem, a number of ongoing studies are evaluating combination of blinatumomab with chemotherapy for Ph- ALL and with TKI for Ph+ ALL.

A recent update reported the outcome of blina treatment in pediatric patients with R/R B ALL in an expanded access study [70]. Treatment-emergent (TE) and treatment-related (TR) adverse events (AEs) were the primary endpoints. Morphologic CR and MRD response by PCR or flow cytometry were the secondary endpoints. At the time of the report, 98 patients were treated (median age, 8.5 [range 0.4-17.0] years). The median follow-up was 12.2 months (range 0.5-14.1). These patients were heavily pretreated. A median of 2 cycles (range 1-5) were administered, with 4 patients completing 5 cycles of blina. Virtually all patients experienced a TEAE whereas $77 \%$ had TRAEs. CRS was seen in $16 \%$, with $2 \%$ severe. There were 9 grade 5 fatal AEs unrelated to blina treatment. Among the 98 patients, $60 \%(n=59)$ achieved CR and 48\% had MRD negativity. Among the 59 CR patients, 27 (46\%) proceeded to allo-HSCT. The median OS was 13.0 months. In conclusion, blina induced MRD negativity in almost half of the patients, including patients with $t(17 ; 19)$. In this study, 4 patients who had prior blina treatment were re-treated and 3 achieved CR again. Blina has now been approved as a treatment option for pediatric patients with R/R ALL (Table 1).

Another retrospective analysis reported data on blina for CNS disease in 11 patients with B ALL [71]. Among the 11 patients, 10 had R/R ALL, 6 had Ph- ALL and 3 with $\mathrm{Ph}+\mathrm{ALL}$. Of the 11 patients, 10 had systemic disease, only 1 with CNS only disease. Among the 11 patients who received blina, 3 had single agent blina, 4 in combination with BCR-ABL TKI, and 4 in combination with systemic chemotherapy. Intrathecal chemotherapy was given to all patients. Severe CNS toxicity was reported in 2 patients. Five of the 6 patients $(83 \%)$ with active CNS disease became negative in CSF after blina therapy. There were 3 patients with positive CNS leukemic involvement on imaging studies. Among these 3 patients, 1 had CR, 1 had PR, and 1 had signs of inflammation. In conclusion, blina is safe and effective in B ALL patients with active CNS disease when given in combination with systemic and intrathecal chemotherapy. Currently, it remains unclear whether blina can penetrate the blood-brain barrier. In this regard, CAR T cells appear to have an advantage for CNS disease since it has been reported that CAR T cells were found in the CSF and are effective against CNS diseases in both hematological and solid tumors [72-75].

CRS is one of the major complications from blina therapy $[50,59]$. IL- 6 cytokine is found to be elevated and believed to be a major mediator of CRS [74, 76]. In a recent analysis updated at the 2018 ASH Annual Meeting, CRS was reported in 39 cases out of 1000 patients treated with blina [77]. Six of the 39 cases received tocilizumab, an IL- 6 receptor antibody, 3 of the 6 patients received concurrent corticosteroids. Blina was interrupted and later restarted once CRS is resolved. CRS in all 6 cases resolved, and 3 cases resumed blina infusion. Among the 6 cases, 4 cases discontinued blina 
therapy. Recent studies on CAR T related toxicities have indicated that IL- 1 and IL- 6 are mediators of CRS, and IL- 6 antagonist does not abrogate cytotoxicity of CAR T cells $[57,78,79]$. It is therefore possible that tocilizumab and IL-1 receptor antagonist may be used early as prophylaxis in addition to therapy. Clinical studies are ongoing for these clinical applications [57].

\section{Novel BiTE antibodies in pre-clinical development CD3 X CD19 bi-valent BiTE}

To enhance binding to leukemia cells expressing low-level CD19 molecules, bi-valent CD3 x CD19 BiTE antibodies, A-329, were produced [80]. The bi-valent A-329 BiTE was shown to be more potent in CD19 binding than the mono-valent format $\mathrm{A}-319$ and in vitro human B cell killing (EC50 $0.2 \mathrm{pM}$ vs $3.4 \mathrm{pM}$ ). A-329 was confirmed to have greater cytotoxicity against a human diffuse large B cell lymphoma (DLBCL) cell line with a low expression of CD19 antigen. In monkey studies, the CD19 bi-valent A-329 BiTE was confirmed in vivo to have potent $B$ cell killing, yet the adverse events were comparable between the mono-valent and bi-valent BiTE antibodies. In conclusion, the bi-valent A-329 appeared to have advantage in targeting tumor stem cells with low CD19 expression.

\section{CD3 x CD20 full-length BiTE}

DuoBody-CD3xCD20 (GEN3013) is a novel BiTE targeting CD20-expressing $B$ cells [81]. Different from blina, this DuoBody is a full-length bispecific IgG1 immunoglobulin with an effector function-silenced Fc region. This full-length BiTE was shown to be highly active in vitro with low picomolar $\mathrm{EC}_{50}$ towards a diverse panel of B cell lines.

\section{CD3 x CD79b BiTE}

$\mathrm{CD} 79 \mathrm{~b}$ is a pan-B cell marker and a component of the B cell receptor complex. CD79b is commonly used for the diagnosis of $\mathrm{B}$ cell leukemia and lymphomas. CD3 $\mathrm{x}$ CD79b BiTE was shown to induce $\mathrm{T}$ cell-dependent cytotoxicity towards CD79b expressing B cells [82]. The BiTE was shown to be active against $B$ cell malignant cell lines as well as primary cells from B cell leukemia and lymphomas. These preclinical data were promising and further studies are needed for clinical applications.

\section{Antibody-drug conjugate (ADC) against CD22}

CD22 is a common biomarker for B cells [83, 84]. It is expressed in B cells and in most cases of B-ALL. CD19 antigen loss has been observed to be a common mechanism of relapse after CD19-directed BiTE and CAR T cell therapies, yet $\mathrm{CD} 22$ remains detected in such cases. Therefore, CD22 antigen serves as a good target to treat R/R ALL [85].
Inotuzumab ozogamicin (INO) is an antibody-drug conjugate that consists of a humanized anti-CD22 monoclonal antibody linked to a cytotoxic agent calicheamicin which can cause double-strand DNA breaks and lead to apoptosis [86-88]. After the conjugate antibody binds to CD22, the CD22-conjugate complex is rapidly internalized. The calicheamicin is then released and results in apoptosis. In a large randomized phase III trial in adults with R/R ALL, single-agent INO was compared with commonly used salvage chemotherapy regimens [26]. The study demonstrated a significantly higher $\mathrm{CR}$ rate in the INO group than that in the chemotherapy group $(80.7 \%$ vs $29.4 \% ; p<0.001)$, and a longer duration of remission (4.6 months vs 3.1 months; $p=0.03$ ). INO has been approved to treat adult $\mathrm{R} / \mathrm{R}$ pre-B-ALL (Table 2). Sino-occlusive syndrome (SOS, also known as veno-occlusive disease (VOD)) with liver function abnormality was reported to be a major adverse event [89, 90]. This treatment should be carefully planned particularly when allo-HSCT is being considered to minimize SOS complications. For patients planning to receive an allogeneic transplant, treatment with inotuzumab ozogamicin should be limited to 2 cycles of induction or the fewest number of cycles required to achieve a $\mathrm{CR} / \mathrm{CRi}$ (if $\mathrm{CR} / \mathrm{CRi}$ is not achieved after 2 cycles).

There are three immunotherapy options currently available for R/R B cell ALL, blina, INO, CD19-targeted CAR T, tisagenlecleucel $[25,26,28,68,69]$. It has been reported that tisagenlecleucel is effective in those $R / R$ ALL patients who have failed blina [91]. "Off-the-shelf" third-party universal CAR T cells were also reported to be effective in R/R ALL who have failed blina therapy [92-94]. It remains unclear whether INO is effective in R/R ALL refractory to blina single agent. One case report described effective rescue with INO for a patient with R/R ALL from CML blast crisis who has failed

Table 2 Inotuzumab ozogamicin for relapsed or refractory B cell acute lymphoblastic leukemia

\begin{tabular}{llll}
\hline & Day 1 & Day 8 & Day 15 \\
\hline $\begin{array}{lll}\text { Induction* } \\
\text { Cycle 1 }\end{array}$ & $0.8 \mathrm{mg} / \mathrm{m}^{2}$ & $0.5 \mathrm{mg} / \mathrm{m}^{2}$ & $0.5 \mathrm{mg} / \mathrm{m}^{2}$ \\
$\begin{array}{c}\text { Cycle length } \\
\text { Consolidation }\end{array}$ & 21 days & & \\
$\begin{array}{l}\text { Dose } \\
\text { Cycle length }\end{array}$ & $0.5 \mathrm{mg} / \mathrm{m}^{2}$ & $0.5 \mathrm{mg} / \mathrm{m}^{2}$ & $0.5 \mathrm{mg} / \mathrm{m}^{2}$ \\
\hline
\end{tabular}

*This may be repeated if patients do not achieve CR/CRi after cycle 1, though cycle length after cycle 1 should be 28 days

\#For patients planning to receive an allogeneic transplant, treatment with inotuzumab ozogamicin should be limited to 2 cycles of induction or the fewest number of cycles required to achieve a CR/CRi (if CR/CRi not achieved after 2 cycles) 
blina therapy [95]. In this blina-refractory ALL, INO induced morphological CR but MRD remained positive.

\section{Novel ADC antibodies targeting B cells in preclinical and clinical development}

Since CD79b is highly prevalent in B cell leukemia and lymphomas, CD79b-targeted ADCs have been in active preclinical and clinical development. The cytotoxic moieties include MMAE and DM1 that inhibit microtubule polymerization (polatuzumab vedotin, DCDS4501A) [96-99]. These CD79b-targeted ADCs have been tested in phase I/II clinical trials in B cell lymphomas. Early results are promising and the study on polatuzumab vedotin is completing (NCT01691898).

Another CD22 antibody was linked to MMAE in a new ADC targeting CD22 expressing B cells [98, 100]. The agent, pinatuzumab vedotin, was shown to be active in the preclinical studies. A multi-center, open-label, phase I study of this agent in B cell lymphoma and CLL has completed patient enrollment (NCT01209130).

\section{New regimens incorporating antibodies Blinatumomab + TKI}

Five TKIs have been approved for the treatment of chronic myeloid leukemia. These include imatinib, nilotinib, dasatinib, bosutinib, and ponatinib [101-103]. TKIs are routinely added to the therapy regimens for $\mathrm{Ph}$ + ALL [1, 7, 18, 31]. Several studies are ongoing to evaluate the efficacy and safety of combination of TKIs (dasatinib or ponatinib) with blina for Ph+ ALL. These regimens may become chemo-sparing therapy for $\mathrm{Ph}+$ ALL.

A retrospective analysis of French experience was recently reported in using blina + ponatinib (blina/pona) in 15 patients ( 9 male/ 6 female) with relapsed $\mathrm{Ph}+\mathrm{ALL}$ ( 2 blast crisis, 4 with T351I mutation) [104]. A median number of 3 cycles of blina was infused while ponatinib was given continuously. Among the 15 patients, 11 received an initial dose of $45 \mathrm{mg}$ ponatinib once daily, 4 had $30 \mathrm{mg}$. A third of the patients stopped ponatinib and $47 \%$ stopped blina due to neurologic events. The cytogenetic CR was $93 \%(n=14)$, and complete molecular CR was achieved in 12 patients. Two patients had CNS relapse while in molecular remission. The median follow-up for alive patients was 8 months (range 2.630.2 ) and the median OS was 8.5 months (range 1.730.2 ). In conclusion, the blina/pona combination was effective and tolerable in relapsed $\mathrm{Ph}+\mathrm{ALL}$ patients and may serve as an effective chemo-sparing salvage regimen. A prospective trial is ongoing (NCT03263572).

In a separate retrospective analysis of single center experience from the Memorial Sloan-Kettering Cancer Center, 11 patients (6 female $/ 5$ male) were identified. Among them, 7 received ponatinib, 3 dasatinib, and 1 nilotinib. Blina was infused at the standard dose and schedule [105]. Seven patients with +MRD turned MRD negative after blina/TKI therapy. Three patients proceeded to allo-HSCT. With a median follow-up of 7.7 months (range 3.2-16.0 months), the median OS has not been reached. Three patients developed grade 1 CRS and no neurotoxicity was observed. Relatively higher risk of transaminitis was seen in the blina/pona combination. In conclusion, this blina/TKI combination was safe and effective as a consolidation regimen for patients with $\mathrm{MRD}+\mathrm{Ph}+\mathrm{ALL}$ and may serve as a bridge therapy prior to allo-HSCT.

To further enhance the blina efficacy through immune checkpoint inhibition, a multi-center phase I dose-escalation study combining blina with nivolumab and ipilimumab is ongoing in R/R CD19+ ALL patients [106]. Patients with prior blina and/or allo-HSCT were also eligible. The treatment may continue up to 5 cycles of blinatumomab and 1 year of nivolumab/ipilimumab. Eight adults with a median age of 55 (range 25-75) were enrolled at dose level I. Transaminitis and chemical pancreatitis were observed in $20 \%$ of the patients. Infusion-related reactions to nivolumab were considered as a DLT. Among 5 evaluable patients, 4 achieved MRD negative $\mathrm{CR}$. In conclusion, the blina/nivolumab combination in R/R ALL is safe and tolerable. Ipilimumab dose escalation is being started in this ongoing study.

\section{Antibodies + chemotherapy regimens \\ Rituximab + intensive chemotherapy}

CD20 expression has served as a reliable biomarker for both diagnosis and therapy of $\mathrm{B}$ cell malignancies. In general, CD20 positivity is defined as expression of CD20 in greater than or equal to $20 \%$ of the blast cells in the NCCN guideline (www.NCCN.org). Rituximab is now routinely added to the chemotherapy regimens for CD20+ ALL and has been shown to increase event-free survival (EFS) [37, 38].

\section{Blinatumomab + hyper-CVAD}

To increase MRD negativity and decrease chemotherapy toxicities by reducing intensive chemotherapy, a phase 2 single-arm study was done to evaluate adding blina after completion of 4 cycles of hyper-CVAD for patients $\geq 14$ years with newly diagnosed ALL [107]. After a total of 4 cycles of hyper-CVAD, 4 cycles of blina were administered as consolidation therapy. Intrathecal prophylaxis with methotrexate and cytarabine were given during the first 4 cycles of hyper-CVAD. In addition, rituximab or ofatumumab was added to hyper-CVAD cycles for those patients with CD20+ ALL (ofatumumab if CD20 $\geq 1 \%$ cells). For maintenance, POMP (6-mercaptopurine, vincristine, methotrexate, prednisone) was given on cycles $1-3,5-7,9-11$, and 13-15 alternating with 3 cycles of 
blinatumomab on cycles 4,8 , and 12 . The primary endpoint was RFS and secondary endpoints were OS, overall response rate (ORR), and MRD negativity rate.

At the last report, 17 patients were treated and only one patient had CD20 expression. Fourteen patients were evaluable. The ORR was $100 \%$ and the MRD negativity was $93 \%$ after the first cycle of therapy. A median of 4 cycles (range 1-4) of chemotherapy and 4 cycles (range 0-4) of blina were administered. No early death was reported. A total of 14 patients completed hyper-CVAD and initiated the blinatumomab phase. Among them, 9 patients have completed hyper-CVAD and blinatumomab sequential therapy and started maintenance therapy.

Two patients developed grade 3 adverse events attributable to blinatumomab. One patient had transient grade 3 CRS and the other had grade 3 ataxia. Both recovered after transient interruption of blinatumomab therapy and dexamethasone administration. The median follow-up was 14 months (range 3-20 months). At the update, OS was $94 \%$ among 17 patients and 14 of them in the first CR. The 1-year RFS rate was 77\% (95\% CI 42-93\%) and the 1-year OS rate was 90\% (95\% CI $47-$ 99\%). In conclusion, the sequential combination of hyper-CVAD and blinatumomab in newly diagnosed B-ALL is safe. The preliminary results are encouraging. This study also incorporated 3 cycles of blina in the maintenance phase. This study is important since it assesses the activity of blina both in consolidation and in maintenance in the context of reducing hyper-CVAD chemotherapy cycles to 4 from conventional 8 cycles. The POMP maintenance cycles are also reduced from usually 3 years to 12 months.

\section{MiniHCVD-INO}

To increase clinical benefit in R/R ALL patients and minimize chemotoxicities, INO was added to a modified hyper-CVAD regimen, miniHCVD in a phase II trial [108]. In the mini-hyper-CVD (miniHCVD) trial, anthracycline was omitted and dexamethasone was given at half dose, whereas methotrexate dose was reduced $75 \%$ and cytarabine reduced to $0.5 \mathrm{~g} / \mathrm{m} 2 \mathrm{q} 12 \mathrm{~h} \times 4$ doses. The doses and schedules of the agents are summarized in Table 3. ORR and OS were the primary end points. A total of 59 patients were included in the analysis, with a median age of 35 years (range 18-87 years). The ORR was $78 \%$ (59\% CR) and 1 -year OS rate was $46 \%$. The quality of the response is of particular interest as the responders had a MRD negativity rate of $82 \%$. There were hyperbilirubinemia $(14 \% ; n=8)$ and VOD/SOS $(n=9$, $15 \%)$. To minimize the toxicity, INO dosage was lowered and ursodiol was added later in the trial protocol. With a median follow-up of 24 months, the median OS reached 11 months. Not surprisingly, earlier initiation of therapy with this regimen led to better outcome. The study reported 1-year OS rates for patients treated in salvage 1 , salvage 2 , and salvage 3 or beyond at $57 \%$, $26 \%$, and $39 \%$, respectively $(p=.03)$. The median OS of

Table 3 MiniHCVD-inotuzumab ozogamicin regimen for acute lymphoblastic leukemia

\begin{tabular}{|c|c|c|c|}
\hline Treatment type & Schedule & Drug & Dose \\
\hline \multirow[t]{8}{*}{ Intensive phase } & \multirow[t]{3}{*}{ Cycles $1,3,5,7$} & Cyclophosphamide & $150 \mathrm{mg} / \mathrm{m}^{2}$ every $12 \mathrm{~h}$, days $1-3$ \\
\hline & & Dexamethasone & $20 \mathrm{mg} / \mathrm{d}$, days $1-4$ and $11-14$ \\
\hline & & Vincristine & $2 \mathrm{mg}$ flat dose, days 1 and 8 \\
\hline & \multirow[t]{2}{*}{ Cycles 2, 4, 6, 8} & Methotrexate & $250 \mathrm{mg} / \mathrm{m}^{2}$, day 1 \\
\hline & & Cytarabine & $0.5 \mathrm{~g} / \mathrm{m}^{2}$ every $12 \mathrm{~h}$, days 2 and 3 \\
\hline & Cycle 1 & Inotuzumab & $1.3 \mathrm{mg} / \mathrm{m}^{2}$, day 3 \\
\hline & Cycles 2, 3, 4 & Inotuzumab & $1.0 \mathrm{mg} / \mathrm{m}^{2}$, day 3 \\
\hline & Cycles 1, 2, 3, 4 & Rituximab* & $375 \mathrm{mg} / \mathrm{m}^{2}$, days 1 and 8 \\
\hline \multirow[t]{4}{*}{ Maintenance therapy } & Months 1-12 & Vincristine & $2 \mathrm{mg} / \mathrm{d}$ every month \\
\hline & Months 1-12 & Prednisone & $50 \mathrm{mg} / \mathrm{d}$ for 5 days every month \\
\hline & Months 1-36 & 6-Mercaptopurine & 50 mg PO twice daily \\
\hline & Months 1-36 & Methotrexate & $10 \mathrm{mg} / \mathrm{m}^{2} \mathrm{PO}$ weekly \\
\hline \multirow[t]{2}{*}{ Central nervous system prophylaxis } & Cycles 1, 3 & IT MTX-AraC & MTX $12 \mathrm{mg}$ on day 2 , AraC $100 \mathrm{mg}$ day 8 \\
\hline & Cycles 2, 4 & IT AraC-MTX & AraC $100 \mathrm{mg}$ on day 5, MTX $12 \mathrm{mg}$ day 8 \\
\hline \multirow[t]{2}{*}{ Supportive care } & Cycles 1-8 & Pegfilgrastim & 6 mg subcutaneously day 4 \\
\hline & Cycles 1-5 & Ursodiol & 300 mg, 3 times daily \\
\hline
\end{tabular}

Note: *Rituximab was administered in patients with CD20 expression of $20 \%$ or higher. It was noted that the schedules of rituximab and CNS prophylaxis have been modified in the latest publications and variations exist since the trials are still ongoing [108, 109]. For details on correct doses and schedules, those from original publications should be followed

Inotuzumab denotes inotuzumab ozogamicin; IT intrathecal, MTX methotrexate, AraC cytarabine 
patients in the first salvage was 17 months which is very encouraging when compared with 9 months in historical series treated with INO or blina in the same institution.

The outcome of this study was compared through a post hoc inverse probability of treatment weighing analysis with similar patients treated with single agent INO $(n=84)$. The ORRs and 1-year OS rates of miniHCVD + INO were significantly better than those treated with INO alone [108]. The treatment appeared to be a good bridging therapy to induce patients into remission followed by allo-HSCT since $44 \%$ of the patients were able to receive subsequent allo-HSCT.

This miniHCVD-INO regimen is being studied in a phase 2 trial at the MD Anderson Cancer Center (Houston, TX, USA) in newly diagnosed elderly ( $\geq 60)$ ALL patients [109]. Progression-free survival (PFS) was the primary endpoint. Fifty-two patients were evaluable, median age 68 years (64-72). The ORR was $98 \%$. After a median follow-up of 29 months (13-48), a 2-year PFS was $59 \%$. The 2 - and $3-$ year OS were $66 \%$ and $56 \%$, respectively. Median PFS was 35 months (95\% CI 16.3 to not reached) and the median OS was not reached. Prolonged thrombocytopenia was the most frequent severe adverse event (81\%). SOS/VOD was observed (8\%). Treatment-related death rate was $12 \%$.

In real-world database analysis, majority of older patients with ALL did not receive cytotoxic chemotherapy, mostly attributable to the possibility that these patients were thought to be unsuitable for intensive chemotherapy by the treating physicians [110-113]. In one analysis with 235 patients who were treated with cytotoxic chemotherapy, the median OS was 10.2 months (95\% CI 8.3-12.7) [114]. In this trial in an older patient population treated with miniHCVD-INO, the median OS was not yet reached after a median follow-up of 29 months. In the GMALL study which enrolled 268 older patients with $\mathrm{Ph}-\mathrm{ALL}$, a subset of 43 patients who received a modified chemotherapy regimen with optimized CNS prophylaxis and consolidation therapy, the CR rate was $86 \%$, and 5-year OS was 52\% [115]. These results are similar to those obtained from the miniHCVD-INO frontline trial in older patients. Therefore, this low-intensity miniHCVD-INO combination regimen may open a new avenue for induction therapy of older patients with B-ALL. The efficacy of this regimen should be confirmed in a randomized phase 3 study.

\section{MiniHCVD-INO-Blinatumomab}

As a single agent, both INO and blina were shown in randomized studies to be better than salvage chemotherapies $[25,26]$. Therefore, new trials are incorporating blinatumomab into the miniHCVD-INO regimen in an attempt to further improve the outcome for ALL patients [116-119]. In these studies, the treatment was divided into 3 phases: intensification, consolidation, and maintenance (Fig. 1, Table 4). Four cycles of intensive chemotherapy with miniHCVD as described above are given. Instead of monthly dosing, the INO dose is divided into day 2 and day 8 of each cycle (Fig. 1). The total dosage of INO was also reduced for each cycle. Blinatumomab is given in the 4 consolidation cycles, followed by maintenance with 4 more cycles given on month 4, 8, 12, and 16 (Table 4). The POMP-blina chemotherapy maintenance is given for a total of $16 \mathrm{cy}$ cles (Fig. 1, Table 4). Addition of blinatumomab makes it possible to reduce POMP maintenance cycles from 3 years to 12 months.

In the combination trial of miniHCVD + INO + blina for newly diagnosed older ALL patients, 58 patients were treated at the last report [117]. Among the 58 patients, 31 had CD20 expression $\geq 20 \%$ and received rituximab. Fifty-four patients were evaluable for morphological responses. The ORR was $95 \%(n=53, \mathrm{CR}, n=47$; CRp, $\mathrm{n}$ $=5$; CRi, $n=1)$. The overall MRD negativity was $95 \%$ in 57 evaluable patients. There was no day-30 mortality. Among the 57 patients with CR, 8 relapsed, 3 proceeded to allo-HSCT, and 31 continued on therapy or completed maintenance. A total of 17 patients died in CR/ CRp. The rate of SOS was $8-11 \%$. The median follow-up was 28 months (2-68 months). The 3-year OS rate was $54 \%$. When this result was compared to a similar historical cohort of older patients treated with hyper-CVAD \pm rituximab $(n=77)$, the miniHCVD + INO \pm blina led to significantly higher 3 -year OS ( $54 \%$ vs $32 \% ; p=0.002$ ). This new combination regimen appears to be safe and effective in elderly patients with newly diagnosed Ph- ALL. Randomized studies are needed to confirm this new immunotherapy-based lighter chemotherapy.

The miniHCVD $+\mathrm{INO} \pm$ blina regimen is ongoing in $\mathrm{R} / \mathrm{R}$ ALL and has been recently updated $[116,118]$. A total of 84 patients were treated including 17 patients with miniHCVD + INO + blina [118]. The treatment schedule and dosages have been published and are summarized in Fig. 1 and Table 4 [116]. The median age was 35 (range 9-87), and the median follow-up was 31 months (range 0.1-64.1). These patients were heavily pretreated and $23 \%$ of them had failed prior allo-HSCT. The ORR was $80 \%$ (CR, 58\%; CRp/CRi, $21 \%$ ), and $81 \%$ achieved MRD negativity, with better response in earlier lines of salvage therapy. Thirty-four patients (40\%) proceeded to allo-HSCT. Three-year OS was $33 \%$. SOS rate was reduced from $15 \%$ to $0 \%$ when the INO dose was split to two doses each cycle. This study showed again that this low-intensity immunotherapy-containing miniHCVD + INO + blina is safe and effective in R/R heavily pretreated ALL patients. In addition, 4 cycles of blinatumomab as consolidation therapy increase the 


\section{MiniHCVD-INO-Blinatumomab regimen}

Intensive Phase (cycle 1-4)

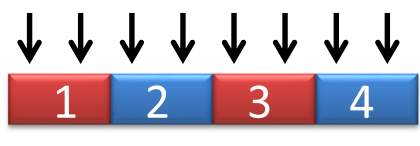

Consolidative Phase (cycle 5-8)

$$
\begin{array}{l|l|l|l|}
\hline 5 & 6 & 7 & 8
\end{array}
$$

Maintenance Phase

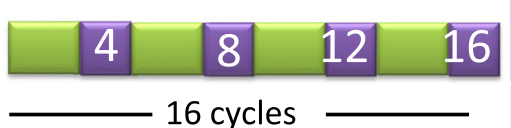

\begin{tabular}{|l|l|l|}
$\begin{array}{l}\text { Inotuzumab } \\
\text { ozogamicin }\end{array}$ & $\begin{array}{l}\text { Total dose } \\
\mathrm{mg} / \mathrm{M}^{2}\end{array}$ & $\begin{array}{l}\text { Dose \& schedule } \\
\mathrm{mg} / \mathrm{M}^{2}\end{array}$ \\
\hline Cycle 1 & 0.9 & $0.6 \mathrm{D} 2$ \& 0.3 D8 \\
\hline Cycle 2,3,4 & 0.6 & $0.3 \mathrm{D} 2$ \& D8
\end{tabular}

Fig. 1 The diagrammatic schema of miniHCVD-inotuzumab ozogamicin-blinatumomab regimen. This was adapted from Jabbour et al. (2018) and Short et al. (2018). Detailed dosages and schedules are summarized in Table 4. miniHCVD low-dose hyper-fractionated cyclophosphamide, vincristine, dexamethasone. MTX methotrexate. INO inotuzumab ozogamicin; POMP prednisone, vincristine, methotrexate, mercaptopurine; D day

Table 4 miniHCVD-inotuzumab ozogamicin-blinatumomab regimen for acute lymphoblastic leukemia

\begin{tabular}{|c|c|c|c|}
\hline Treatment type & Schedule & Drug & Dose \\
\hline \multirow[t]{8}{*}{ Intensive phase } & \multirow[t]{3}{*}{ Cycles 1,3} & Cyclophosphamide & $150 \mathrm{mg} / \mathrm{m}^{2}$ every $12 \mathrm{~h}$, days $1-3$ \\
\hline & & Dexamethasone & $20 \mathrm{mg} / \mathrm{d}$, days $1-4$ and $11-14$ \\
\hline & & Vincristine & 2 mg flat dose, days 1 and 8 \\
\hline & \multirow[t]{2}{*}{ Cycles 2, 4} & Methotrexate & $250 \mathrm{mg} / \mathrm{m}^{2}$, day 1 \\
\hline & & Cytarabine & $0.5 \mathrm{~g} / \mathrm{m}^{2}$ every 12 hours, days 2 and 3 \\
\hline & Cycle 1 & Inotuzumab & $0.6 \mathrm{mg} / \mathrm{m}^{2}$, day $2 \& 0.3 \mathrm{mg} / \mathrm{m}^{2}$, day 8 \\
\hline & Cycles 2, 3, 4 & Inotuzumab & $0.3 \mathrm{mg} / \mathrm{m}^{2}$, days 2 and 8 \\
\hline & Cycles 1, 2, 3, 4 & Rituximab* & $375 \mathrm{mg} / \mathrm{m}^{2}$ day 1 and 8 \\
\hline \multirow[t]{2}{*}{ Consolidation phase } & Cycle 5 & Blinatumomab & $9 \mu \mathrm{g} /$ day, days $1-4 ; 28 \mu \mathrm{g} /$ day days $5-28$ \\
\hline & Cycles 6, 7, 8 & Blinatumomab & $28 \mathrm{\mu g} /$ day days $1-28$ \\
\hline \multirow[t]{5}{*}{ Maintenance therapy } & Months 1-3, 5-7, 9-11, 13-15 & Vincristine & $2 \mathrm{mg} / \mathrm{d}$ every month \\
\hline & Months 1-3, 5-7, 9-11, 13-15 & Prednisone & $50 \mathrm{mg} / \mathrm{d}$ for 5 days every month \\
\hline & Months 4, 8, 12, 16 & Blinatumomab & 28 mg/day days $1-28$ \\
\hline & Months 1-3, 5-7, 9-11, 13-15 & 6-Mercaptopurine & 50 mg PO twice daily \\
\hline & Months 1-3, 5-7, 9-11, 13-15 & Methotrexate & $10 \mathrm{mg} / \mathrm{m}^{2} \mathrm{PO}$ weekly \\
\hline \multirow[t]{2}{*}{ Central nervous system prophylaxis } & Cycles 1, 3 & IT MTX-AraC & MTX $12 \mathrm{mg}$ on day 2 , AraC $100 \mathrm{mg}$ day 8 \\
\hline & Cycles 2, 4 & IT AraC-MTX & AraC $100 \mathrm{mg}$ on day 5, MTX $12 \mathrm{mg}$ day 8 \\
\hline \multirow[t]{2}{*}{ Supportive care } & Cycles 1-4 & Pegfilgrastim & 6 mg subcutaneously day 4 \\
\hline & Cycles 1-5 & Ursodiol & 300 mg, 3 times daily \\
\hline
\end{tabular}

Note: For Intensive phase, inotuzumab ozogamicin (INO) is administered in two split doses on day 2 and day 8 . The first dose of INO is $0.6 \mathrm{mg} / \mathrm{m} 2$, each subsequent dose is $0.3 \mathrm{mg} / \mathrm{m} 2$. In the Consolidation phase, blinatumomab was initiated at $9 \mu \mathrm{g} /$ day for 4 days and then escalated to $28 \mu \mathrm{g} /$ day by continuous IV infusion for a total of 4 weeks followed by 2 weeks treatment-free interval, and the cycle is repeated every 6 weeks. *Rituximab was administered in patients with CD20 expression of $20 \%$ or higher. It was noted that the schedules of rituximab and CNS prophylaxis have been modified in the latest publications, and variations exist since the trials are still ongoing $[116,117]$. For details on correct doses and schedules, those from original publications should be followed Inotuzumab denotes inotuzumab ozogamicin; IT intrathecal, MTX methotrexate, AraC cytarabine 
interval between the last dose of inotuzumab ozogamicin and allo-HSCT. The long interval between INO and allo-HSCT as well as split-dose INO appears to markedly reduce SOS risk. More patients are needed for the triple combination regimen to better assess the risk of adding the antibodies, and randomized study is need to ascertain the value of this novel combination regimen.

When the patients who were treated as first salvage on this regimen were analyzed $(n=48)$, ORR was $92 \%$ and CR $73 \%$ [116]. MRD negativity was $93 \%$. With a median follow-up of 31 months, the median OS was 25 months. Half of the 48 patients proceeded to allo-HSCT. This outcome was compared with historical controls of similar patients treated in the same institution with either salvage chemotherapy or INO, and the combination regimen miniHCVD-INO +/- blina had better outcome than the intensive salvage chemotherapy or INO alone. Therefore, this low-intensity regimen appears to lead to better outcome for first salvage therapy for R/R ALL patients. The results however require confirmation in randomized studies.

In summary, it appears that this low-intensity chemotherapy regimen with 4 cycles of miniHCVD + mini-methotrexate-cytarabine in combination with immunotherapy is promising. The trials are ongoing and the regimen is still going through modifications. The modifications included splitting INO dosage to minimize SOS/VOD, and blinatumomab was added to consolidation phase as well as to the maintenance phase for better elimination of MRD. CD20 expression is typically considered positive in $20 \%$ cells and rituximab was added in those cases $[108,116]$. It appears that the schedules of rituximab and CNS prophylaxis had variations in miniHCVD-INO-blina low-intensity regimen when compared with those used in conventional hyper-CVAD regimens.

\section{Conclusions and future perspectives}

TKIs, bispecific antibodies, antibody-drug conjugates, and CAR T cells are changing the treatment paradigm for ALL. More targeted agents including BTK inhibitors (ibrutinib, acalabrutinib), BCL-2 inhibitor (venetoclax), and immune checkpoint inhibitors are being studied for ALL therapy [120-123]. It remains unclear at this time how to position and sequence these new agents and regimens. When and how to use allo-HSCT in the overall treatment algorithm of B cell precursor ALL is another challenge. The current trend points to the direction to use less cytotoxic chemotherapy and more targeted agents as well as immunotherapeutic agents including blina, INO, and CAR T cells. Studies are ongoing to use these agents in frontline settings, particularly in older patient population. It is foreseeable that with targeted, more efficacious and less toxic regimens, the outcome from ALL therapy will be significantly improved.

\section{Abbreviations}

ADC: Antibody-drug conjugate; ALL: Acute lymphoblastic leukemia;

CAR: Chimeric antigen receptor; CRS: Cytokine release syndrome

\section{Acknowledgements}

We are grateful that Drs. Elias Jabbour and Nicholas J. Short from the MD Anderson Cancer Center reviewed Tables 3 and 4 and helped revising the regimen schedules. DL is a Professor of Medicine, Department of Medicine, New York Medical College and Westchester Medical Center, Valhalla, NY 10595, USA.

\section{Funding}

The study is partly supported by the First Affiliated Hospital of Zhengzhou University, Zhengzhou, China. This work was supported partly by the National and Fujian Provincial Key Clinical Specialty Program, The Construction project of Fujian Hematology Medical Center (Min201704, Ting Yang), and the National Natural Science Foundation of China (81570162, Ting Yang).

\section{Availability of data and materials}

The material supporting the conclusion of this review has been included within the article.

\section{Authors' contributions}

$\mathrm{DL}$ designed the study and drafted the manuscript. JZ prepared the tables and figure. All authors participated in the process of drafting and revising the manuscript. All authors read and approved the final manuscript.

Ethics approval and consent to participate

This is not applicable for this review.

\section{Consent for publication}

This is not applicable for this review.

\section{Competing interests}

The authors declare that they have no competing interests.

\section{Publisher's Note}

Springer Nature remains neutral with regard to jurisdictional claims in published maps and institutional affiliations.

\section{Author details}

${ }^{1}$ Department of Oncology, The First Affiliated Hospital of Zhengzhou University, Zhengzhou 450052, China. ²Department of Hematology, The Affiliated Cancer Hospital of Zhengzhou University and Henan Cancer Hospital, Zhengzhou, China. ${ }^{3}$ Department of Hematology, Fujian Institute of Hematology, Fujian Provincial Key Laboratory of Hematology, Fujian Medical University Union Hospital, Fuzhou 350001, Fujian, China.

Received: 12 January 2019 Accepted: 1 February 2019

Published online: 08 February 2019

References

1. Curran E, Stock W. How I treat acute lymphoblastic leukemia in older adolescents and young adults. Blood. 2015;125(24):3702-10.

2. Hunger SP, Mullighan CG. Acute lymphoblastic leukemia in children. N Engl J Med. 2015;373(16):1541-52.

3. Litzow MR, Ferrando AA. How I treat T-cell acute lymphoblastic leukemia in adults. Blood. 2015;126(7):833-41.

4. Pui C-H, Campana D, Pei D, Bowman WP, Sandlund JT, Kaste SC, Ribeiro RC, Rubnitz JE, Raimondi SC, Onciu M, Coustan-Smith E, Kun LE, Jeha S, Cheng C, Howard SC, Simmons V, Bayles A, Metzger ML, Boyett JM, Leung W, Handgretinger R, Downing JR, Evans WE, Relling MV. Treating childhood acute lymphoblastic leukemia without cranial irradiation. N Engl J Med. 2009;360(26):2730-41.

5. Terwilliger T, Abdul-Hay M. Acute lymphoblastic leukemia: a comprehensive review and 2017 update. Blood Cancer J. 2017;7:e577. 
6. Linker CA, Levitt LJ, O'Donnell M, Ries CA, Link MP, Forman SJ, Farbstein MJ. Improved results of treatment of adult acute lymphoblastic leukemia. Blood. 1987;69(4):1242-8.

7. Frey NV, Luger SM. How I treat adults with relapsed or refractory Philadelphia chromosome-negative acute lymphoblastic leukemia. Blood. 2015;126(5):589-96.

8. Schrappe M, Hunger SP, Pui C-H, Saha V, Gaynon PS, Baruchel A, Conter V, Otten J, Ohara A, Versluys AB, Escherich G, Heyman M, Silverman LB, Horibe K, Mann G, Camitta BM, Harbott J, Riehm H, Richards S, Devidas M, Zimmermann M. Outcomes after induction failure in childhood acute lymphoblastic leukemia. N Engl J Med. 2012;366(15):1371-81.

9. Roberts KG, Li Y, Payne-Turner D, Harvey RC, Yang Y-L, Pei D, McCastlain K, Ding L, Lu C, Song G, Ma J, Becksfort J, Rusch M, Chen S-C, Easton J, Cheng J, Boggs K, Santiago-Morales N, lacobucci I, Fulton RS, Wen J, Valentine M, Cheng C, Paugh SW, Devidas M, Chen I-M, Reshmi S, Smith A, Hedlund E, Gupta P, et al. Targetable kinase-activating lesions in Ph-like acute lymphoblastic leukemia. N Engl J Med. 2014;371(11):1005-15.

10. Cheng S, Inghirami G, Cheng S, Tam W. Simple deep sequencing-based post-remission MRD surveillance predicts clinical relapse in B-ALL. J Hematol Oncol. 2018;11(1):105.

11. Jabbour E, Pui $\mathrm{CH}$, Kantarjian H. Progress and innovations in the management of adult acute lymphoblastic leukemia. JAMA Oncol. 2018; 4(10):1413-20.

12. Rossari F, Minutolo F, Orciuolo E. Past, present, and future of Bcr-Abl inhibitors: from chemical development to clinical efficacy. J Hematol Oncol. 2018;11(1):84

13. Jabbour $E$, Kantarjian $H$, Ravandi F, Thomas D, Huang $X$, Faderl $S$, Pemmaraju N, Daver N, Garcia-Manero G, Sasaki K, Cortes J, Garris R, Yin CC, Khoury JD, Jorgensen J, Estrov Z, Bohannan Z, Konopleva M, Kadia T, Jain N, DiNardo C, Wierda W, Jeanis V, O'Brien S. Combination of hyper-CVAD with ponatinib as first-line therapy for patients with Philadelphia chromosomepositive acute lymphoblastic leukaemia: a single-centre, phase 2 study. Lancet Oncol. 2015;16(15):1547-55.

14. Daver N, Thomas D, Ravandi F, Cortes J, Garris R, Jabbour E, Garcia-Manero G, Borthakur G, Kadia T, Rytting M, Konopleva M, Kantarjian H, O'Brien S. Final report of a phase II study of imatinib mesylate with hyper-CVAD for the front-line treatment of adult patients with Philadelphia chromosomepositive acute lymphoblastic leukemia. Haematologica. 2015;100(5):653-61.

15. Benjamini O, Dumlao TL, Kantarjian H, O'Brien S, Garcia-Manero G, Faderl S, Jorgensen J, Luthra R, Garris R, Thomas D, Kebriaei P, Champlin R, Jabbour E, Burger J, Cortes J, Ravandi F. Phase II trial of hyper CVAD and dasatinib in patients with relapsed Philadelphia chromosome positive acute lymphoblastic leukemia or blast phase chronic myeloid leukemia. Am J Hematol. 2014;89(3):282-7.

16. Ravandi F, O'Brien S, Thomas D, Faderl S, Jones D, Garris R, Dara S, Jorgensen J, Kebriaei P, Champlin R, Borthakur G, Burger J, Ferrajoli A, Garcia-Manero G, Wierda W, Cortes J, Kantarjian H. First report of phase 2 study of dasatinib with hyper-CVAD for the frontline treatment of patients with Philadelphia chromosome-positive $(\mathrm{Ph}+)$ acute lymphoblastic leukemia. Blood. 2010;116(12):2070-7.

17. Thomas DA, Faderl S, Cortes J, O'Brien S, Giles FJ, Kornblau SM, GarciaManero G, Keating MJ, Andreeff M, Jeha S, Beran M, Verstovsek S, Pierce S, Letvak L, Salvado A, Champlin R, Talpaz M, Kantarjian H. Treatment of Philadelphia chromosome-positive acute lymphocytic leukemia with hyperCVAD and imatinib mesylate. Blood. 2004;103(12):4396-407.

18. Abou Dalle I, Jabbour E, Short NJ, Ravandi F. Treatment of Philadelphia chromosome-positive acute lymphoblastic leukemia. Curr Treat Options in Oncol. 2019;20(1):4.

19. June $\mathrm{CH}, \mathrm{O}^{\prime}$ Connor RS, Kawalekar OU, Ghassemi S, Milone MC. CAR T cell immunotherapy for human cancer. Science. 2018;359(6382):1361-5.

20. June $\mathrm{CH}$, Sadelain M. Chimeric antigen receptor therapy. N Engl J Med. 2018;379(1):64-73.

21. Sadelain M, Brentjens R, Riviere I, Park J. CD19 CAR therapy for acute lymphoblastic leukemia. Am Soc Clin Oncol Educ Book. 2015; 35:e360-3.

22. Sadelain M, Rivière I, Riddell S. Therapeutic T cell engineering. Nature. 2017;545:423.

23. Wang Z, Wu Z, Liu Y, Han W. New development in CAR-T cell therapy. J Hematol Oncol. 2017;10(1):53.

24. Zhang C, Liu J, Zhong JF, Zhang X. Engineering CAR-T cells. Biomarker Res. 2017:5(1):22

25. Kantarjian H, Stein A, Gökbuget N, Fielding AK, Schuh AC, Ribera J-M, Wei A Dombret H, Foà R, Bassan R, Arslan Ö, Sanz MA, Bergeron J, Demirkan F,
Lech-Maranda E, Rambaldi A, Thomas X, Horst H-A, Brüggemann M, Klapper W. Wood BL, Fleishman A, Nagorsen D, Holland C, Zimmerman Z, Topp MS. Blinatumomab versus chemotherapy for advanced acute lymphoblastic leukemia. N Engl J Med. 2017;376(9):836-47.

26. Kantarjian HM, DeAngelo DJ, Stelljes M, Martinelli G, Liedtke M, Stock W, Gokbuget N, O'Brien S, Wang K, Wang T, Paccagnella ML, Sleight B, Vandendries E, Advani AS. Inotuzumab ozogamicin versus standard therapy for acute lymphoblastic leukemia. N Engl J Med. 2016;375(8):740-53.

27. Weng J, Lai P, Qin L, Lai Y, Jiang Z, Luo C, Huang X, Wu S, Shao D, Deng C, Huang L, Lu Z, Zhou M, Zeng L, Chen D, Wang Y, Chen X, Geng S, Robert W, Tang Z, He C, Li P, Du X. A novel generation 1928zT2 CAR T cells induce remission in extramedullary relapse of acute lymphoblastic leukemia. J Hematol Oncol. 2018;11(1):25.

28. Zhang L-N, Song Y, Liu D. CD19 CAR-T cell therapy for relapsed/refractory acute lymphoblastic leukemia: factors affecting toxicities and long-term efficacies. J Hematol Oncol. 2018;11(1):41.

29. Wang J, Hu Y, Huang $\mathrm{H}$. Current development of chimeric antigen receptor T-cell therapy. Stem Cell Investigation. 2018;5:44.

30. Faderl S, Thomas DA, O'Brien S, Ravandi F, Garcia-Manero G, Borthakur G, Ferrajoli A, Verstovsek S, Ayoubi M, Rytting M, Feliu J, Kantarjian HM Augmented hyper-CVAD based on dose-intensified vincristine, dexamethasone, and asparaginase in adult acute lymphoblastic leukemia salvage therapy. Clin Lymphoma Myeloma Leuk. 2011;11(1):54-9.

31. Jabbour E, Short NJ, Ravandi F, Huang X, Daver N, DiNardo CD, Konopleva M, Pemmaraju N, Wierda W, Garcia-Manero G, Sasaki K, Cortes J, Garris R, Khoury JD, Jorgensen J, Jain N, Alvarez J, O'Brien S, Kantarjian H. Combination of hyper-CVAD with ponatinib as first-line therapy for patients with Philadelphia chromosome-positive acute lymphoblastic leukaemia: long-term follow-up of a single-centre, phase 2 study. Lancet Haematol. 2018;5(12):e618-27.

32. Jain P, Kantarjian H, Ravandi F, Thomas D, O'Brien S, Kadia T, Burger J, Borthakur G, Daver N, Jabbour E, Konopleva M, Cortes J, Pemmaraju N, Kelly MA, Cardenas-Turanzas M, Garris R, Faderl S. The combination of hyperCVAD plus nelarabine as frontline therapy in adult T-cell acute lymphoblastic leukemia and T-lymphoblastic lymphoma: MD Anderson Cancer Center experience. Leukemia. 2014;28(4):973-5.

33. Thomas DA, O'Brien S, Cortes J, Giles FJ, Faderl S, Verstovsek S, Ferrajoli A, Koller C, Beran M, Pierce S, Ha CS, Cabanillas F, Keating MJ, Kantarjian H. Outcome with the hyper-CVAD regimens in lymphoblastic lymphoma. Blood. 2004;104(6):1624-30.

34. Thomas DA, O'Brien S, Faderl S, Garcia-Manero G, Ferrajoli A, Wierda W, Ravandi F, Verstovsek S, Jorgensen JL, Bueso-Ramos C, Andreeff M, Pierce S, Garris R, Keating MJ, Cortes J, Kantarjian HM. Chemoimmunotherapy with a modified hyper-CVAD and rituximab regimen improves outcome in de novo Philadelphia chromosome-negative precursor B-lineage acute lymphoblastic leukemia. J Clin Oncol. 2010;28(24):3880-9.

35. Kantarjian H, Thomas D, O'Brien S, Cortes J, Giles F, Jeha S, Bueso-Ramos CE, Pierce S, Shan J, Koller C, Beran M, Keating M, Freireich EJ. Long-term follow-up results of hyperfractionated cyclophosphamide, vincristine, doxorubicin, and dexamethasone (hyper-CVAD), a dose-intensive regimen, in adult acute lymphocytic leukemia. Cancer. 2004;101(12):2788-801.

36. Garcia-Manero G, Kantarjian HM. The hyper-CVAD regimen in adult acute lymphocytic leukemia. Hematol Oncol Clin North Am. 2000;14(6):1381-96.

37. Maury S, Chevret $S$, Thomas $X$, Heim D, Leguay T, Huguet $F$, Chevallier $P$, Hunault M, Boissel N, Escoffre-Barbe M, Hess U, Vey N, Pignon JM, Braun T, Marolleau JP, Cahn JY, Chalandon Y, Lheritier V, Beldjord K, Bene MC, Ifrah $\mathrm{N}$, Dombret $\mathrm{H}$, for G:Rituximab in B-lineage adult acute lymphoblastic leukemia. N Engl J Med 2016, 375(11):1044-1053.

38. Ribrag V, Koscielny S, Bosq J, Leguay T, Casasnovas O, Fornecker L-M, Recher C, Ghesquieres H, Morschhauser F, Girault S, Gouill SL, Ojeda-Uribe M, Mariette C, Cornillon J, Cartron G, Verge V, Chassagne-Clément C, Dombret H, Coiffier B, Lamy T, Tilly H, Salles G. Rituximab and dose-dense chemotherapy for adults with Burkitt's lymphoma: a randomised, controlled, open-label, phase 3 trial. Lancet. 2016;387(10036):2402-11.

39. Thomas DA, Faderl S, O'Brien S, Bueso-Ramos C, Cortes J, Garcia-Manero G, Giles FJ, Verstovsek S, Wierda WG, Pierce SA, Shan J, Brandt M, Hagemeister FB, Keating MJ, Cabanillas F, Kantarjian $H$. Chemoimmunotherapy with hyper-CVAD plus rituximab for the treatment of adult Burkitt and Burkitt-type lymphoma or acute lymphoblastic leukemia. Cancer. 2006;106(7):1569-80.

40. Wang M, Fayad L, Cabanillas F, Hagemeister F, McLaughlin P, Rodriguez MA, Kwak LW, Zhou Y, Kantarjian H, Romaguera J. Phase 2 trial of rituximab plus 
hyper-CVAD alternating with rituximab plus methotrexate-cytarabine for relapsed or refractory aggressive mantle cell lymphoma. Cancer. 2008; 113(10):2734-41.

41. Chihara D, Cheah CY, Westin JR, Fayad LE, Rodriguez MA, Hagemeister FB, Pro B, McLaughlin P, Younes A, Samaniego F, Goy A, Cabanillas F, Kantarjian H, Kwak LW, Wang ML, Romaguera JE. Rituximab plus hyper-CVAD alternating with MTX/Ara-C in patients with newly diagnosed mantle cell lymphoma: 15-year follow-up of a phase II study from the MD Anderson Cancer Center. Br J Haematol. 2016:172(1):80-8.

42. Wang K, Wei G, Liu D. CD19: a biomarker for B cell development, lymphoma diagnosis and therapy. Exp Hematol Oncol. 2012;1(1):36.

43. Fichtner $M$, Dreyling $M$, Binder $M$, Trepel $M$. The role of $B$ cell antigen receptors in mantle cell lymphoma. J Hematol Oncol. 2017;10(1):164.

44. Carter RH, Myers R. Germinal center structure and function: lessons from CD19. Semin Immunol. 2008:20(1):43-8.

45. Carter RH, Wang Y, Brooks S. Role of CD19 signal transduction in B cell biology. Immunol Res. 2002;26(1-3):45-54.

46. Liu B, Song Y, Liu D. Clinical trials of CAR-T cells in China. J Hematol Oncol 2017;10(1):166

47. Im A, Pavletic SZ. Immunotherapy in hematologic malignancies: past, present, and future. J Hematol Oncol. 2017;10(1):94.

48. Wei G, Ding L, Wang J, Hu Y, Huang H. Advances of CD19-directed chimeric antigen receptor-modified $T$ cells in refractory/relapsed acute lymphoblastic leukemia. Exp Hematol Oncol. 2017;6(1):10.

49. Nagorsen D, Kufer P, Baeuerle PA, Bargou R. Blinatumomab: a historical perspective. Pharmacol Ther. 2012;136(3):334-42.

50. Topp MS, Gokbuget N, Zugmaier G, Degenhard E, Goebeler ME, Klinger M, Neumann SA, Horst HA, Raff T, Viardot A, Stelljes M, Schaich M, KohneVolland R, Bruggemann M, Ottmann OG, Burmeister T, Baeuerle PA, Nagorsen D, Schmidt M, Einsele H, Riethmuller G, Kneba M, Hoelzer D, Kufer $P$, Bargou RC. Long-term follow-up of hematologic relapse-free survival in a phase 2 study of blinatumomab in patients with MRD in B-lineage ALL. Blood. 2012;120(26):5185-7.

51. Topp MS, Gokbuget N, Zugmaier G, Klappers P, Stelljes M, Neumann S Viardot A, Marks R, Diedrich H, Faul C, Reichle A, Horst HA, Bruggemann M, Wessiepe D, Holland C, Alekar S, Mergen N, Einsele H, Hoelzer D, Bargou RC. Phase II trial of the anti-CD19 bispecific T cell-engager blinatumomab shows hematologic and molecular remissions in patients with relapsed or refractory B-precursor acute lymphoblastic leukemia. J Clin Oncol. 2014; 32(36):4134-40

52. Topp MS, Kufer P, Gokbuget N, Goebeler M, Klinger M, Neumann S, Horst HA, Raff T, Viardot A, Schmid M, Stelljes M, Schaich M, Degenhard E, KohneVolland R, Bruggemann M, Ottmann O, Pfeifer H, Burmeister T, Nagorsen D, Schmidt M, Lutterbuese R, Reinhardt C, Baeuerle PA, Kneba M, Einsele H, Riethmuller G, Hoelzer D, Zugmaier G, Bargou RC. Targeted therapy with the T-cell-engaging antibody blinatumomab of chemotherapy-refractory minimal residual disease in B-lineage acute lymphoblastic leukemia patients results in high response rate and prolonged leukemia-free survival. J Clin Oncol. 2011;29(18):2493-8.

53. Traynor K. Blinatumomab approved for rare leukemia. Am J Health Syst Pharm. 2015;72(2):90

54. Zhang X, Yang Y, Fan D, Xiong D. The development of bispecific antibodies and their applications in tumor immune escape. Exp Hematol Oncol. 2017; 6(1):12.

55. Nägele V, Kratzer A, Zugmaier G, Holland C, Hijazi Y, Topp MS, Gökbuget N, Baeuerle PA, Kufer P, Wolf A, Klinger M. Changes in clinical laboratory parameters and pharmacodynamic markers in response to blinatumomab treatment of patients with relapsed/refractory ALL. Ex Hematol Oncol. 2017; 6(1):14.

56. Portell CA, Wenzell CM, Advani AS. Clinical and pharmacologic aspects of blinatumomab in the treatment of B-cell acute lymphoblastic leukemia. Clin Pharmacol. 2013;5(Suppl 1):5-11.

57. Liu D, Zhao J. Cytokine release syndrome: grading, modeling, and new therapy. J Hematol Oncol. 2018;11(1):121.

58. Porter D, Frey N, Wood PA, Weng Y, Grupp SA. Grading of cytokine release syndrome associated with the CAR T cell therapy tisagenlecleucel. J Hematol Oncol. 2018;11(1):35.

59. Topp MS, Gokbuget N, Stein AS, Zugmaier G, O'Brien S, Bargou RC, Dombret $H$, Fielding AK, Heffner L, Larson RA, Neumann S, Foa R, Litzow M, Ribera JM, Rambaldi A, Schiller G, Bruggemann M, Horst HA, Holland C, Jia C, Maniar T, Huber B, Nagorsen D, Forman SJ, Kantarjian HM. Safety and activity of blinatumomab for adult patients with relapsed or refractory Bprecursor acute lymphoblastic leukaemia: a multicentre, single-arm, phase 2 study. Lancet Oncol. 2014;16(1):57-66.

60. Wang Z, Han W. Biomarkers of cytokine release syndrome and neurotoxicity related to CAR-T cell therapy. Biomarker Res. 2018;6(1):4.

61. Aboudalle I, Kantariian HM, Short NJ, Khouri M, Takahashi K, Ohanian MN, Borthakur G, Konopleva MY, Daver NG, Estrov ZE, Alvarado Y, Jain N, Ravandi F, Garcia-Manero G, Velasquez M, Nasnas P, Brien SM, Jabbour EJ. Phase II study of blinatumomab in patients with B-cell lineage acute lymphocytic leukemia with positive minimal/measurable residual disease. Blood. 2018;132(Suppl 1):5212

62. Gokbuget N, Dombret H, Bonifacio M, Reichle A, Graux C, Faul C, Diedrich H, Topp MS, Bruggemann M, Horst HA, Havelange V, Stieglmaier J, Wessels H, Haddad V, Benjamin JE, Zugmaier G, Nagorsen D, Bargou RC. Blinatumomab for minimal residual disease in adults with B-cell precursor acute lymphoblastic leukemia. Blood. 2018;131(14):1522-31.

63. Short NJ, Jabbour E, Albitar M, de Lima M, Gore L, Jorgensen J, Logan AC, Park J, Ravandi F, Shah B, Radich J, Kantarjian H. Recommendations for the assessment and management of measurable residual disease in adults with acute lymphoblastic leukemia: a consensus of North American experts. Am J Hematol. 2019;94(2):257-65.

64. Martinelli G, Boissel N, Chevallier P, Ottmann O, Gokbuget N, Topp MS, Fielding AK, Rambaldi A, Ritchie EK, Papayannidis C, Sterling LR, Benjamin J, Stein A. Complete hematologic and molecular response in adult patients with relapsed/refractory Philadelphia chromosome-positive B-precursor acute lymphoblastic leukemia following treatment with blinatumomab: results from a phase II, single-arm, multicenter study. J Clin Oncol. 2017; 35(16):1795-802.

65. Kohnke T, Krupka C, Tischer J, Knosel T, Subklewe M. Increase of PD-L1 expressing B-precursor ALL cells in a patient resistant to the CD19/CD3-bispecific T cell engager antibody blinatumomab. J Hematol Oncol. 2015;8(1):111.

66. Aboudalle I, Kantarjian HM, Short NJ, Ravandi F, Sasaki K, Garcia-Manero G, Montalban-Bravo G, Cortes JE, Benton CB, Issa GC, Khouri M, Nasnas P, Brien SM, Jabbour EJ. Long term follow-up on phase 2 study on the efficacy and safety of blinatumomab in adult patients with relapsed refractory Bprecursor acute lymphoblastic leukemia. Blood. 2018;132(Suppl 1):4017.

67. Jabbour E, Dull J, Yilmaz M, Khoury JD, Ravandi F, Jain N, Einsele H, GarciaManero G, Konopleva M, Short NJ, Thompson PA, Wierda W, Daver N, Cortes J, O'Brien S, Kantarjian H, Topp MS. Outcome of patients with relapsed/refractory acute lymphoblastic leukemia after blinatumomab failure: no change in the level of CD19 expression. Am J Hematol. 2018; 93(3):371-4

68. Maude SL, Laetsch TW, Buechner J, Rives S, Boyer M, Bittencourt H, Bader P, Verneris MR, Stefanski HE, Myers GD, Qayed M, De Moerloose B, Hiramatsu H, Schlis K, Davis KL, Martin PL, Nemecek ER, Yanik GA, Peters C, Baruchel A, Boissel N, Mechinaud F, Balduzzi A, Krueger J, June CH, Levine BL, Wood P, Taran $\mathrm{T}$, Leung $\mathrm{M}$, Mueller KT, et al. Tisagenlecleucel in children and young adults with B-cell lymphoblastic leukemia. N Engl J Med. 2018;378(5):439-48.

69. Park JH, Rivière I, Gonen M, Wang X, Sénéchal B, Curran KJ, Sauter C, Wang Y, Santomasso B, Mead E, Roshal M, Maslak P, Davila M, Brentjens RJ, Sadelai M. Long-term follow-up of CD19 CAR therapy in acute lymphoblastic leukemia. N Engl J Med. 2018;378:449-59.

70. Locatelli F, Zugmaier G, Bader P, Jeha S, Schlegel P-G, Bourquin J-P, Handgretinger R, Brethon B, Rossig C, Chen-Santel C. High molecular remission rate in pediatric patients (pts) with relapsed/refractory B-cell precursor acute lymphoblastic leukemia ( $r / r$ ALL) treated with Blinatumomab: rialto an open-label, multicenter, expanded access study. Blood. 2018;132(Suppl 1):1375

71. Alfayez M, Kantarjian HM, Short NJ, Assi R, Khouri M, Ravandi F, Paul S, Rausch CR, Nasnas P, Borthakur G, DiNardo CD, Kadia TM, Daver NG, GarciaManero G, Naqvi K, Bose P, Brien SM, Cortes JE, Jabbour EJ. Safety and efficacy of blinatumomab in patients with central nervous system (CNS) disease: a single institution experience. Blood. 2018;132(Suppl 1):2702.

72. Hu Y, Wu Z, Yu J, Wang J, Wei G, Wu W, Luo Y, Shi J, Xiao L, Huang H. Efficacy of CD19-targeted chimeric antigen receptor $T$ cells in the treatment of relapsed extramedullary B-cell acute lymphoblastic leukemia (B-ALL) and diffuse large B-cell lymphoma (DLBCL). J Clin Oncol. 2017;35(15_suppl):e14549.

73. Zhang X, Lu X-A, Yang J, LV F, Xiong M, Zhang J, Zhou X, He T, Lu P: Efficacy and safety of CD19 chimeric antigen receptor (CAR) T cell therapy for B-cell acute lymphocytic leukemia (B-cell $A L L$ ) in a large cohort including patients with extramedullary disease (EMD), high leukemia 
burden, BCR-ABL (+) mutation,TP53 mutation, and post-transplant relapse. Blood 2018, 132(Suppl 1):280-280

74. Porter DL, Levine BL, Kalos M, Bagg A, June CH. Chimeric antigen receptormodified T cells in chronic lymphoid leukemia. N Engl J Med. 2011;365(8): 725-33

75. Brown CE, Alizadeh D, Starr R, Weng L, Wagner JR, Naranjo A, Ostberg JR, Blanchard MS, Kilpatrick J, Simpson J, Kurien A, Priceman SJ, Wang X, Harshbarger TL, D'Apuzzo M, Ressler JA, Jensen MC, Barish ME, Chen M, Portnow J, Forman SJ, Badie B. Regression of glioblastoma after chimeric antigen receptor T-cell therapy. N Engl J Med. 2016;375(26):2561-9.

76. Porter DL, Kalos M, Zheng Z, Levine B, June C. Chimeric antigen receptor therapy for B-cell malignancies. J Cancer. 2011;2:331-2.

77. Choudhry J, Parson M, Wright J. A retrospective review of tocilizumab for the management of blinatumomab (a bispecific T cell engager)-induced cytokine release syndrome (CRS). Blood. 2018;132(Suppl 1):5211.

78. Giavridis T, van der Stegen SJC, Eyquem J, Hamieh M, Piersigilli A, Sadelain M. CAR T cell-induced cytokine release syndrome is mediated by macrophages and abated by IL-1 blockade. Nat Med. 2018;24(6):731-8.

79. Norelli M, Camisa B, Barbiera G, Falcone L, Purevdorj A, Genua M, Sanvito F, Ponzoni M, Doglioni C, Cristofori P, Traversari C, Bordignon C, Ciceri F, Ostuni R, Bonini C, Casucci M, Bondanza A. Monocyte-derived IL-1 and IL-6 are differentially required for cytokine-release syndrome and neurotoxicity due to CAR T cells. Nat Med. 2018;24(6):739-48.

80. Cui Y, Huang Z, Zhang X, Shen W, Chen H, Wen Z, Qi B, Luo L, Tan Y, Wu Y, Kung A, Yan X. CD3-activating bi-specific antibody targeting CD19 on B cells in mono- and bi-valent format. Blood. 2018;132(Suppl 1):4169.

81. Hiemstra IH, Engelberts PJ, de Jong B, Schuurhuis DH, Salcedo TW, Verploegen S, van der Zee M, Gerritsen AF, Losic N, Horbach S, Oliveri R, Lammerts van Bueren JJ, Autzen Usher P, Schuurman J, PWHI P, ECW B. Duobody-CD3xCD20 shows unique and potent preclinical anti-tumor activity in vivo and in vitro, and is being evaluated clinically in patients with B-cell malignancies. Blood. 2018;132(Suppl 1):1664.

82. Sun $L L$, Chen $X$, Chen $Y$, Dennis MS, Ellerman D, Johnson C, Mathieu M, Oldendorp A, Polson AG, Reyes A, Stefanich E, Wang H, Wang P, Zheng B, Ebens AJ. Pre-clinical characterization of T cell-dependent bispecific antibody anti-CD79b/CD3 as a potential therapy for B cell malignancies. Blood. 2014;124(21):4507

83. Stamenkovic I, Seed B. The B-cell antigen CD22 mediates monocyte and erythrocyte adhesion. Nature. 1990;345(6270):74-7.

84. Wilson $\mathrm{GL}$, Fox $\mathrm{CH}$, Fauci AS, Kehrl JH. cDNA cloning of the B cell membrane protein CD22: a mediator of B-B cell interactions. J Exp Med. 1991;173(1):137-46.

85. Ereno-Orbea J, Sicard T, Cui H, Mazhab-Jafari MT, Benlekbir S, Guarne A, Rubinstein JL, Julien JP. Molecular basis of human CD22 function and therapeutic targeting. Nat Commun. 2017;8(1):764

86. Kantarjian $\mathrm{H}$, Thomas D, Jorgensen J, Jabbour E, Kebriaei P, Rytting M, York S, Ravandi F, Kwari M, Faderl S, Rios MB, Cortes J, Fayad L, Tarnai R, Wang SA, Champlin R, Advani A, O'Brien S. Inotuzumab ozogamicin, an anti-CD22calecheamicin conjugate, for refractory and relapsed acute lymphocytic leukaemia: a phase 2 study. Lancet Oncol. 2012;13(4):403-11.

87. Kantarijan H, Thomas D, Jorgensen J, Kebriaei P, Jabbour E, Rytting M, York S, Ravandi F, Garris R, Kwari M, Faderl S, Cortes J, Champlin R, O'Brien S. Results of inotuzumab ozogamicin, a CD22 monoclonal antibody, in refractory and relapsed acute lymphocytic leukemia. Cancer. 2013;119(15): 2728-36.

88. Ricart AD. Antibody-drug conjugates of calicheamicin derivative: gemtuzumab ozogamicin and inotuzumab ozogamicin. Clin Cancer Res. 2011;17(20):6417-27

89. George B, Kantarjian $H$, Jabbour E, Jain N. Role of inotuzumab ozogamicin in the treatment of relapsed/refractory acute lymphoblastic leukemia. Immunotherapy. 2016;8(2):135-43.

90. Kantarjian HM, DeAngelo DJ, Advani AS, Stelljes M, Kebriaei P, Cassaday RD, Merchant AA, Fujishima N, Uchida T, Calbacho M, Ejduk AA, O'Brien SM, Jabbour EJ, Zhang H, Sleight BJ, Vandendries ER, Marks DI. Hepatic adverse event profile of inotuzumab ozogamicin in adult patients with relapsed or refractory acute lymphoblastic leukaemia: results from the open-label, randomised, phase 3 INO-VATE study. Lancet Haematol. 2017;4(8):e387-98.

91. Grupp SA, Kalos M, Barrett D, Aplenc R, Porter DL, Rheingold SR, Teachey DT, Chew A, Hauck B, Wright JF, Milone MC, Levine BL, June CH. Chimeric antigen receptor-modified T cells for acute lymphoid leukemia. N Engl J Med. 2013;368(16):1509-18.
92. Benjamin R, Graham C, Yallop D, Jozwik A, Ciocarlie O, Jain N, Jabbour EJ, Maus MV, Frigault M, Boissel N, Larghero J, Baruchel A, Mohty M, De Moerloose B, Bloor A, Frey NV, Zinaï A, Balandraud S, Philippe A, Fouliard S, Gauthier L, Pauly J, Konto C, Bermingham C, Veys P, Qasim W. Preliminary data on safety, cellular kinetics and anti-leukemic activity of UCART19, an allogeneic anti-CD19 CAR T-cell product, in a pool of adult and pediatric patients with high-risk CD19+ relapsed/refractory B-cell acute lymphoblastic leukemia. Blood. 2018;132(Suppl 1):896.

93. Qasim W, Zhan H, Samarasinghe S, Adams S, Amrolia P, Stafford S, Butler K, Rivat C, Wright G, Somana K, Ghorashian S, Pinner D, Ahsan G, Gilmour K, Lucchini G, Inglott S, Mifsud W, Chiesa R, Peggs KS, Chan L, Farzeneh F, Thrasher AJ, Vora A, Pule M, Veys P. Molecular remission of infant B-ALL after infusion of universal TALEN gene-edited CAR T cells. Sci Transl Med. 2017;9(374). https://doi.org/10.1126/scitransImed.aaj2013.

94. Zhao J, Lin Q, Song Y, Liu D. Universal CARs, universal T cells, and universal CAR T cells. J Hematol Oncol. 2018;11(1):132.

95. Mansurov A, Byrne M, Krishnan K. Successful salvage with inotuzumab ozogamicin in relapsed/refractory lymphoid blast crisis of chronic myeloid leukemia after failure of multiple lines of therapy including blinatumomab. Blood. 2018;132(Suppl 1):5452.

96. Dornan D, Bennett F, Chen Y, Dennis M, Eaton D, Elkins K, French D, Go MAT, Jack A, Junutula JR, Koeppen H, Lau J, McBride J, Rawstron A, Shi X, Yu N, Yu S-F, Yue P, Zheng B, Ebens A, Polson AG. Therapeutic potential of an anti-CD79b antibody-drug conjugate, anti-CD79b-vc-MMAE, for the treatment of non-Hodgkin lymphoma. Blood. 2009;114(13):2721.

97. Palanca-Wessels MCA, Czuczman M, Salles G, Assouline S, Sehn LH, Flinn I, Patel MR, Sangha R, Hagenbeek A, Advani R, Tilly H, Casasnovas O, Press OW, Yalamanchili S, Kahn R, Dere RC, Lu D, Jones S, Jones C, Chu Y-W, Morschhauser F. Safety and activity of the anti-CD79B antibody-drug conjugate polatuzumab vedotin in relapsed or refractory B-cell nonHodgkin lymphoma and chronic lymphocytic leukaemia: a phase 1 study. Lancet Oncol. 2015;16(6):704-15.

98. Pfeifer M, Zheng B, Erdmann T, Koeppen H, McCord R, Grau M, Staiger A, Chai A, Sandmann T, Madle H, Dörken B, Chu YW, Chen Al, Lebovic D, Salles GA, Czuczman MS, Palanca-Wessels MC, Press OW, Advani R, Morschhauser F, Cheson BD, Lenz P, Ott G, Polson AG, Mundt KE, Lenz G. Anti-CD22 and anti-CD79B antibody drug conjugates are active in different molecular diffuse large B-cell lymphoma subtypes. Leukemia. 2015;29:1578-86.

99. Salles GA, Czuczman MS, Assouline SE, Flinn IW, Sehn LH, Patel M, Sangha R, Tilly H, Advani R, Casasnovas O, Press OW, Yalamanchili S, Kahn R, Lu D, Chai A, Chu Y-W, Morschhauser F. Final results of a phase I study of the anti-CD79b antibody-drug conjugate DCDS4501A in relapsed or refractory (R/R) B-cell non-Hodgkin lymphoma (NHL). Blood. 2013;122(21):4400.

100. Polson AG, Calemine-Fenaux J, Chan P, Chang W, Christensen E, Clark S, de Sauvage FJ, Eaton D, Elkins K, Elliott JM, Frantz G, Fuji RN, Gray A, Harden K, Ingle GS, Kljavin NM, Koeppen H, Nelson C, Prabhu S, Raab H, Ross S, Stephan J-P, Scales SJ, Spencer SD, Vandlen R, Wranik B, Yu S-F, Zheng B, Ebens A. Antibody-drug conjugates for the treatment of non-Hodgkin's lymphoma: target and Linker-drug selection. Cancer Res. 2009;69(6):2358-64.

101. Chamoun K, Kantarjian H, Atallah R, Gonzalez GN, Issa GC, Rios MB, GarciaManero G, Borthakur G, Ravandi F, Jain N, Daver N, Konopleva M, DiNardo CD, Kadia T, Pemmaraju N, Jabbour E, Cortes J. Tyrosine kinase inhibitor discontinuation in patients with chronic myeloid leukemia: a singleinstitution experience. J Hematol Oncol. 2019;12(1):1.

102. Cortes JE, Apperley JF, DeAngelo DJ, Deininger MW, Kota VK, Rousselot $P$, Gambacorti-Passerini C. Management of adverse events associated with bosutinib treatment of chronic-phase chronic myeloid leukemia: expert panel review. J Hematol Oncol. 2018;11(1):143.

103. Ling Y, Xie Q, Zhang Z, Zhang H. Protein kinase inhibitors for acute leukemia. Biomarker Res. 2018:6(1):8.

104. Couturier M-A, Thomas $X$, Huguet F, Berthon C, Simand C, Hicheri $Y$, Hunault M, Chevallier P. Blinatumomab + ponatinib for relapsed Ph1positive acute lymphoblastic leukemia: the French experience. Blood. 2018; 132(Suppl 1):4014

105. King AC, Pappacena J, Tallman MS, Park JH, Geyer MB. Blinatumomab administered concurrently with oral tyrosine kinase inhibitor therapy is a well-tolerated consolidation strategy and eradicates measurable residual disease in adults with Philadelphia chromosome positive acute lymphoblastic leukemia. Blood. 2018;132(Suppl 1):1414.

106. Webster J, Luskin MR, Prince GT, DeZern AE, DeAngelo DJ, Levis MJ, Blackford A, Sharon E, Streicher H, Luznik L, Gojo I. Blinatumomab in 
combination with immune checkpoint inhibitors of PD-1 and CTLA-4 in adult patients with relapsed/refractory (R/R) CD19 positive B-cell acute lymphoblastic leukemia (ALL): preliminary results of a phase I study. Blood. 2018;132(Suppl 1):557.

107. Richard-Carpentier G, Kantarjian HM, Short NJ, Ravandi F, Ferrajoli A, Schroeder HM, Khouri M, Garcia-Manero G, Montalban Bravo G, Cortes JE, Jain N, Konopleva MY, Takahashi K, Sasaki K, Garris RE, Jabbour EJ. A phase II study of the hyper-CVAD regimen in sequential combination with blinatumomab as frontline therapy for adults with B-cell acute lymphoblastic leukemia (B-ALL). Blood. 2018;132(Suppl 1):32.

108. Jabbour E, Ravandi F, Kebriaei P, Huang X, Short NJ, Thomas D, Sasaki K, Rytting M, Jain N, Konopleva M, Garcia-Manero G, Champlin R, Marin D, Kadia T, Cortes J, Estrov Z, Takahashi K, Patel Y, Khouri MR, Jacob J, Garris R, O'Brien S, Kantarjian H. Salvage chemoimmunotherapy with inotuzumab ozogamicin combined with mini-hyper-CVD for patients with relapsed or refractory Philadelphia chromosome-negative acute lymphoblastic leukemia: a phase 2 clinical trial. JAMA Oncol. 2018:4(2):230-4.

109. Kantarjian H, Ravandi F, Short NJ, Huang X, Jain N, Sasaki K, Daver N, Pemmaraju N, Khoury JD, Jorgensen J, Alvarado Y, Konopleva M, GarciaManero G, Kadia T, Yilmaz M, Bortakhur G, Burger J, Kornblau S, Wierda W, DiNardo C, Ferrajoli A, Jacob J, Garris R, O'Brien S, Jabbour E. Inotuzumab ozogamicin in combination with low-intensity chemotherapy for older patients with Philadelphia chromosome-negative acute lymphoblastic leukaemia: a single-arm, phase 2 study. Lancet Oncol. 2018;19(2):240-8.

110. Barlev A, Lin WW, Katz A, Hu K, Cong Z, Barber B. Estimating long-term survival of adults with Philadelphia chromosome-negative relapsed/ refractory B-precursor acute lymphoblastic leukemia treated with blinatumomab using historical data. Adv Ther. 2017;34(1):148-55.

111. Gokbuget N, Dombret H, Ribera JM, Fielding AK, Advani A, Bassan R, Chia V, Doubek M, Giebel S, Hoelzer D, Ifrah N, Katz A, Kelsh M, Martinelli G Morgades M, O'Brien S, Rowe JM, Stieglmaier J, Wadleigh M, Kantarjian H. International reference analysis of outcomes in adults with B-precursor Phnegative relapsed/refractory acute lymphoblastic leukemia. Haematologica. 2016;101(12):1524-33.

112. Katz AJ, Chia VM, Schoonen WM, Kelsh MA. Acute lymphoblastic leukemia: an assessment of international incidence, survival, and disease burden. Cancer Causes Control. 2015;26(11):1627-42.

113. Geyer MB, Hsu M, Devlin SM, Tallman MS, Douer D, Park JH. Overall survival among older US adults with ALL remains low despite modest improvement since 1980: SEER analysis. Blood. 2017;129(13):1878.

114. Li S, Molony JT, Chia V, Katz AJ. Patient characteristics and treatment patterns in elderly patients newly diagnosed with acute lymphoblastic leukemia (ALL) using 100\% Medicare ALL data. Blood. 2016;128(22):3981.

115. Goekbuget N, Beck J, Brueggemann M, Burmeister T, Buss EC, Frickhofen N, Huettmann A, Morgner A, Reichle A, Schmidt-Wolf I, Schwartz S, Serve H, Spriewald BM, Starck M, Stelljes M, Viardot A, Wendelin K, Hoelzer D. Moderate intensive chemotherapy including CNS-prophylaxis with liposomal cytarabine is feasible and effective in older patients with Phnegative acute lymphoblastic leukemia (ALL): results of a prospective trial from the german multicenter study group for adult ALL (GMALL). Blood. 2012;120(21):1493.

116. Jabbour E, Sasaki K, Ravandi F, Huang X, Short NJ, Khouri M, Kebriaei P, Burger J, Khoury J, Jorgensen J, Jain N, Konopleva M, Garcia-Manero G, Kadia T, Cortes J, Jacob J, Montalbano K, Garris R, O'Brien S, Kantarjian HM. Chemoimmunotherapy with inotuzumab ozogamicin combined with minihyper-CVD, with or without blinatumomab, is highly effective in patients with Philadelphia chromosome-negative acute lymphoblastic leukemia in first salvage. Cancer. 2018;124(20):4044-55.

117. Short NJ, Jabbour EJ, Ravandi F, Huang X, Jain N, Sasaki K, Pemmaraju N, Daver NG, Khoury JD, Jorgensen JL, Alvarado Y, Konopleva MY, GarciaManero G, Kadia TM, Yilmaz M, Borthakur G, Burger JA, Kornblau SM, Wierda WG, CD DN, Ferrajoli A, Nasnas P, Jacob J, Garris RE, Brien SM, Kantarjian HM. Chemoimmunotherapy with inotuzumab ozogamicin combined with mini-hyper-CVD, with or without blinatumomab, for newly diagnosed older patients with Philadelphia chromosome-negative acute lymphoblastic leukemia: results from a phase II study. Blood. 2018;132(Suppl 1):36.

118. Sasaki K, Kantarjian HM, Ravandi F, Short NJ, Kebriaei P, Huang X, Rytting ME, Jain N, Konopleva MY, Garcia-Manero G, Champlin RE, Kadia TM, Cortes JE, Estrov ZE, Takahashi K, Mace M, Khouri M, Nasnas P, Jacob J, Garris RE, Jabbour EJ. Sequential combination of low-intensity chemotherapy (minihyper-CVD) plus inotuzumab ozogamicin with or without blinatumomab in patients with relapsed/refractory Philadelphia chromosome-negative acute lymphoblastic leukemia (ALL): a phase 2 trial. Blood. 2018;132(Suppl 1):553.

119. Kantarjian $\mathrm{H}$, Jabbour $\mathrm{E}$. Incorporating immunotherapy into the treatment strategies of B-cell adult acute lymphoblastic leukemia: the role of blinatumomab and inotuzumab ozogamicin. Am Soc Clin Oncol Educ Book. 2018;38:574-8.

120. Byrd JC, Furman RR, Coutre SE, Flinn IW, Burger JA, Blum KA, Grant B, Sharman JP, Coleman M, Wierda WG, Jones JA, Zhao W, Heerema NA, Johnson AJ, Sukbuntherng J, Chang BY, Clow F, Hedrick E, Buggy JJ, James DF, O'Brien S. Targeting BTK with ibrutinib in relapsed chronic lymphocytic leukemia. N Engl J Med. 2013;369(1):32-42.

121. Byrd JC, Harrington B, O'Brien S, Jones JA, Schuh A, Devereux S, Chaves J, Wierda WG, Awan FT, Brown JR, Hillmen P, Stephens DM, Ghia P, Barrientos JC, Pagel JM, Woyach J, Johnson D, Huang J, Wang X, Kaptein A, Lannutti BJ, Covey T, Fardis M, McGreivy J, Hamdy A, Rothbaum W, Izumi R, Diacovo TG, Johnson AJ, Furman RR. Acalabrutinib (ACP-196) in relapsed chronic lymphocytic leukemia. N Engl J Med. 2016;374(4):323-32.

122. Perini GF, Ribeiro GN, Pinto Neto JV, Campos LT, Hamerschlak N. BCL-2 as therapeutic target for hematological malignancies. J Hematol Oncol. 2018; 11(1):65.

123. Wang ML, Rule S, Martin P, Goy A, Auer R, Kahl BS, Jurczak W, Advani RH, Romaguera JE, Williams ME, Barrientos JC, Chmielowska E, Radford J, Stilgenbauer S, Dreyling M, Jedrzejczak WW, Johnson P, Spurgeon SE, Li L, Zhang L, Newberry K, Ou Z, Cheng N, Fang B, McGreivy J, Clow F, Buggy JJ, Chang BY, Beaupre DM, Kunkel LA, et al. Targeting BTK with ibrutinib in relapsed or refractory mantle-cell lymphoma. N Engl J Med. 2013;369(6): $507-16$.
Ready to submit your research? Choose BMC and benefit from:
- fast, convenient online submission
- thorough peer review by experienced researchers in your field
- rapid publication on acceptance
- support for research data, including large and complex data types
- gold Open Access which fosters wider collaboration and increased citations
- maximum visibility for your research: over $100 \mathrm{M}$ website views per year
At BMC, research is always in progress.
Learn more biomedcentral.com/submissions 